\title{
Consortium blockchains based traceability system for chicken product supply chain
}

\author{
Yugege Feng, Wenjing Yan*, Min Zuo, and Qingchuan Zhang \\ National Engineering Laboratory for Agri-Product Quality Traceability, Beijing Technology and \\ Business University, Beijing 100048, China
}

\begin{abstract}
In recent years, people pay increasing attention to food safety. Chicken, as the second largest meat consumer goods in China, requires high level quality traceability. However, due to the small monomer and large quantity of live poultry, it is difficult to duplicate the whole chain tracing mode of pig industry. In this paper we use HACCP (Hazard Analysis and Critical Control Points) to analyze the key control points in the chicken supply chain, and design the traceability code for each chicken product. The traceability system applies the consortium blockchains technology to realize the secure and trusted up-chaining of traceability data, which ensures the quality and safety of chicken in the market.
\end{abstract}

Keywords: Chicken supply chain, Traceability systems, HACCP, Consortium blockchains.

\section{Introduction}

In recent years, food safety issues have drawn increasing attention in China. The food traceability systems are efficient solution in food safety issues preventing and detection. Chicken is the second largest meat consumer goods in China. It is very important to build efficient traceability systems within the whole chicken product supply chain including chicken breeding, slaughtering, processing, transportation and retailing. At present, HACCP ${ }^{[1]}$ is an effective and economical analysis of food safe production. Consortium blockchains is a kind of blockchain with identity access mechanism ${ }^{[2]}$. When it is applied to food traceability, it exhibits better performance in Internet Interconnection and information sharing, which is more operability and development prospects.

This paper applied HACCP analysis to determine the key points of chicken product supply chain, and designs an effective chicken products traceability system. The system allows information collection on the chain are carried out at the key points of chicken production, provides a complete information channel of forward collection and reverse traceability. The system aims to provide supervision services for government regulatory departments, production enterprises and consumers, and ensures the quality and safety of chicken products.

\footnotetext{
* Corresponding author: yanwenjing0423@163.com
} 


\section{HACCP analysis of chicken product supply chain}

\subsection{Chicken product supply chain}

A typical structure of chicken supply chain is presented in Figure 1. Chicken supply chain refers to the network structure mode composed of chicken feeding, chicken breeding, chicken slaughtering and processing, chicken retailing, transportation and terminal consumers [3].

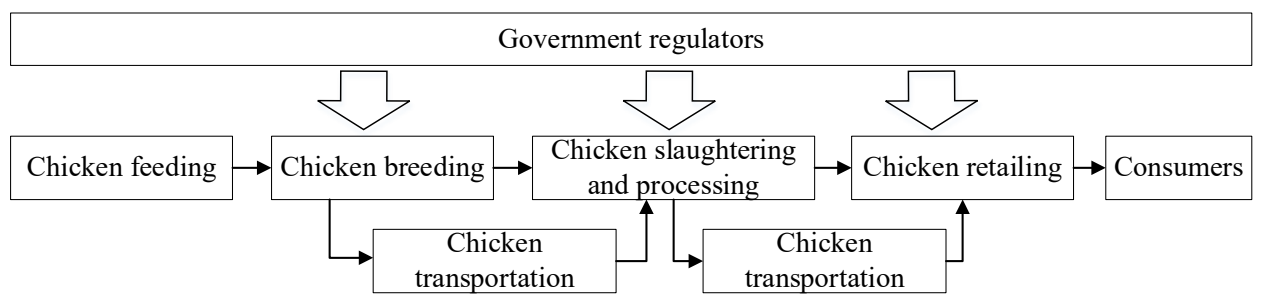

Fig. 1. Structure of chicken supply chain.

\subsection{Critical control points of chicken product supply chain}

According to the structure of chicken supply chain, through a comprehensive analysis of the potential hazards existing in the production process of chicken, the potential biological, chemical and physical hazards that may appear in the production process are evaluated. For each hazard, we estimate the possibility of occurrence and its serious degree. Finally, we determined the critical control points in the production process and incorporate them into HACCP plan. After that, this paper discussed to set the critical limit for every critical control point, through the monitoring of the critical control points, the potential hazards can be effectively prevented, eliminated or reduced to an acceptable level, so as to provide a strong guarantee for the quality and safety of chicken products.

\section{The design of chicken product traceability system based on consortium blockchains}

\subsection{Traceability code coding rules}

The information corelated with traceability code is generated from the whole process information of chicken food supply chain, and the traceability code must unique for each product. Chicken product traceability code consists of main code, attribute code of each process and corresponding attribute value.

Due to the characteristics of small monomer and large quantity in the process of live chicken breeding, it is difficult to identify monomer. Usually, traceability is carried out according to batches, and each batch generates a traceability code. The traceability code is defined as: unified social credit code + product code + origin code + batch code + attribute code + attribute value.

After the live chicken is slaughtered and divided, a unique traceability code is generated for each single product (part) to realize "one product, one code". The traceability code is defined as: unified social credit code + product code + origin code + batch code + single product code + attribute code + attribute value. 
The structure of traceability code is shown in Table 2 . The unified social credit code refers to $<<$ GB32100-2015 Unified Code of Social Credit for Legal Persons and Other Organizations $>>$, the product code refers to $<<\mathrm{GB} / \mathrm{T}$ 26604-2011 Classification of Meat Products $>>$, and the origin code refers to $<<\mathrm{GB} / \mathrm{T} 2260-2007$ Administrative Division Code $>>$. Batch code is composed of hen house number + production date.

Table 1. HACCP plan of chicken food supply chain.

\begin{tabular}{|c|c|c|c|c|c|}
\hline $\begin{array}{c}\text { Critical } \\
\text { control } \\
\text { point }\end{array}$ & Hazard & Critical limit & Monitoring & $\begin{array}{l}\text { Corrective } \\
\text { measures }\end{array}$ & Record \\
\hline Breeding & $\begin{array}{c}\text { Chemistry: } \\
\text { veterinary } \\
\text { pesticide } \\
\text { residues }\end{array}$ & $\begin{array}{c}<<\mathrm{GB} \\
2707-2016, \\
\text { GB } \\
2762-2017>> \\
\text {,Announceme } \\
\text { nt No. } 235 \text { of } \\
\text { Ministry of } \\
\text { agriculture } \\
\end{array}$ & $\begin{array}{l}\text { Certificate of } \\
\text { animal products; } \\
\text { Detection report } \\
\text { of veterinary } \\
\text { drug and } \\
\text { antibiotic } \\
\text { residues }\end{array}$ & $\begin{array}{l}\text { The raw chicken } \\
\text { without } \\
\text { inspection report } \\
\text { refused to } \\
\text { accept; Fast } \\
\text { detection before } \\
\text { next step }\end{array}$ & $\begin{array}{l}\text { Organizati } \\
\text { on, } \\
\text { Sample } \\
\text { name, } \\
\text { Test } \\
\text { results, } \\
\text { etc. }\end{array}$ \\
\hline $\begin{array}{c}\text { CCP2 } \\
\text { Slaughterin } \\
\mathrm{g}\end{array}$ & $\begin{array}{l}\text { Biology: } \\
\text { microbial } \\
\text { contaminati } \\
\text { on }\end{array}$ & $\begin{array}{c}<<\mathrm{NY} \\
467-2001>> \\
<<\mathrm{DB} 11 / \mathrm{T} \\
719-2010>> \\
<<\mathrm{DB} 62 / \mathrm{T} \\
4183.1-2020 \\
>>\end{array}$ & $\begin{array}{c}\text { Factory } \\
\text { inspection } \\
\text { report; Third } \\
\text { party testing } \\
\text { agency or } \\
\text { official } \\
\text { supervision test } \\
\text { report } \\
\end{array}$ & $\begin{array}{l}\text { Raw chicken } \\
\text { without relevant } \\
\text { certificate and } \\
\text { inspection report } \\
\text { refused to accept }\end{array}$ & $\begin{array}{c}\text { Organizatio } \\
\text { n, Sample } \\
\text { name, Test } \\
\text { report, etc. }\end{array}$ \\
\hline Processing & $\begin{array}{l}\text { Chemistry: } \\
\text { food } \\
\text { additives } \\
\text { exceed the } \\
\text { standard }\end{array}$ & $\begin{array}{c}<<\mathrm{GB} \\
2760-2014>>\end{array}$ & $\begin{array}{c}\text { Regular / } \\
\text { Irregular } \\
\text { sampling } \\
\text { inspection within } \\
\text { the enterprise or } \\
\text { regulatory } \\
\text { department }\end{array}$ & $\begin{array}{l}\text { Carry out strict } \\
\text { punishment } \\
\text { Measures for } \\
\text { unqualified } \\
\text { sampling }\end{array}$ & $\begin{array}{c}\text { Instrumen } \\
\mathrm{t} \\
\text { maintenan } \\
\text { ce } \\
\text { Record, } \\
\text { person in } \\
\text { charge of } \\
\text { key } \\
\text { processin } \\
\text { g and } \\
\text { productio } \\
\text { n record } \\
\end{array}$ \\
\hline $\begin{array}{c}\text { Transportati } \\
\text { on }\end{array}$ & $\begin{array}{c}\text { Biology: } \\
\text { microbial } \\
\text { reproductio } \\
\mathrm{n}\end{array}$ & $\begin{array}{c}<<\mathrm{GB} / \mathrm{T} \\
28640-2012> \\
>,<<\mathrm{GB} / \mathrm{T} \\
22005-2009> \\
>,<<\mathrm{GB} / \mathrm{T} \\
24616-2019> \\
>\end{array}$ & $\begin{array}{l}\text { Cold storage and } \\
\text { cold chain } \\
\text { transportation } \\
\text { are adopted; } \\
\text { Temperature } \\
\text { measuring } \\
\text { device is } \\
\text { installed in the } \\
\text { transport vehicle }\end{array}$ & $\begin{array}{l}\text { Record the cargo } \\
\text { damage rate and } \\
\text { punish the } \\
\text { drivers with high } \\
\text { cargo damage } \\
\text { rate }\end{array}$ & $\begin{array}{l}\text { Transport } \\
\text { ation list } \\
\text { and } \\
\text { temperatu } \\
\text { re data }\end{array}$ \\
\hline Retailing & $\begin{array}{c}\text { Biology: } \\
\text { microbial } \\
\text { reproductio } \\
\mathrm{n}\end{array}$ & $\begin{array}{c}<<\mathrm{GB} / \mathrm{T} \\
22502-2008> \\
>,<<\mathrm{GB} / \mathrm{T} \\
21721-2008> \\
>\end{array}$ & $\begin{array}{l}\text { Carry out rapid } \\
\text { detection before } \\
\text { commodity } \\
\text { sales; Check the } \\
\text { goods on sale to } \\
\text { ensure that there } \\
\text { is no pollution }\end{array}$ & $\begin{array}{c}\text { Reject } \\
\text { acceptance of } \\
\text { unqualified } \\
\text { goods by rapid } \\
\text { detection }\end{array}$ & $\begin{array}{l}\text { Quick test } \\
\text { report; } \\
\text { Sales } \\
\text { record }\end{array}$ \\
\hline
\end{tabular}


Table 2. Main code structure of traceability code.

\begin{tabular}{|c|c|c|c|c|}
\hline $\begin{array}{c}\text { Unified social credit } \\
\text { code }^{\mathrm{a}}\end{array}$ & $\begin{array}{l}\text { Product } \\
\text { code }^{\mathrm{b}}\end{array}$ & Origin code & Batch code & Item code ${ }^{c}$ \\
\hline$X_{1} X_{2} \ldots X_{10} \ldots X_{18}$ & $X_{1} \ldots X_{4}$ & $X_{6}$ & $X_{1} \ldots X_{4}+X_{1} \ldots X_{6}$ & $X_{1} \ldots X_{4}$ \\
\hline \multicolumn{5}{|c|}{$\begin{array}{l}{ }^{a} \text { It refers to the identification code of the business entity tracing back to the source. } \\
{ }^{b} \text { When the number of digits is insufficient, } 0 \text { is used to fill in. } \\
{ }^{c} \text { The product code is composed of } 4 \text { Arabic numerals or letters, which is assigned by the } \\
\text { food responsible unit. For prepackaged food and part of bulk food, the processing } \\
\text { enterprise has generated a single product code when it leaves the factory, which can be } \\
\text { used directly when it is sold; For bulk food, the retailer can compile the item code by } \\
\text { itself }{ }^{[4]} \text {. }\end{array}$} \\
\hline
\end{tabular}

In order to facilitate consumers query, the traceability code attribute value data is stored in the blockchain in the database. When consumers input the traceability code in to the chicken product traceability system, the system invokes the attribute code and corresponding attribute value information of each process of the supply chain. At last, the traceability information is displayed to consumers. The corresponding relationship between attribute code and attribute value is shown in Table 3. (take fresh chicken wings as an example)

Table 3. Traceability data structure.

\begin{tabular}{|c|c|l|c|}
\hline $\begin{array}{c}\text { Attribute } \\
\text { code }\end{array}$ & Meaning & \multicolumn{1}{|c|}{ Example of attribute value } \\
\hline BRI & $\begin{array}{c}\text { Breeding } \\
\text { information }\end{array}$ & $\begin{array}{l}\text { \{'breed':'luhua chicken','birthplace':'dezhou city','breeding } \\
\text { enterprise ':'yucheng City Hehui breeding Co., Ltd'\} }\end{array}$ \\
\hline TEI & Test information & $\begin{array}{l}\{\text { 'time ':'2021-06-15','total arsenic ':'0.045','test institution } \\
\text { ':'shandong Detection Technology Co., Ltd'\} }\end{array}$ \\
\hline STI & $\begin{array}{c}\text { Storage } \\
\text { information }\end{array}$ & $\begin{array}{l}\text { \{warehousing time ':'2021-06-14','outbound time } \\
\text { ':'2021-06-15','warehousing operator's name ':'Tom'\} }\end{array}$ \\
\hline TRI & $\begin{array}{c}\text { Transportation } \\
\text { information }\end{array}$ & $\begin{array}{l}\{\text { 'contact number of transport personnel':'1234 ','Start time } \\
\text { of transport':'2021-06-15','temperature on the way':'2 }{ }^{\circ} \mathrm{C} \text { '\} }\end{array}$ \\
\hline SAI & $\begin{array}{c}\text { Sales } \\
\text { information }\end{array}$ & $\begin{array}{l}\text { \{sales company ':'yonghui supermarket','sales date } \\
\text { ':'2021-06-15','sales quantity and unit ':'2.0kg'\} }\end{array}$ \\
\hline
\end{tabular}

\subsection{Information processing based on consortium blockchains}

The chicken product traceability system based on consortium blockchains can guarantee the trusted up-chaining of data, especially the food quality testing data. When the traceability data generated during the processed of breeding, slaughtering, processing, transportation, sales and other process are uploaded in real time through wireless devices, TrustZone and smart contract are used to ensure the consistency and authenticity of the up-chained data. When chicken products are transferred in the supply chain, from breeding to selling, the traceability data should be added to the attribute code and attribute value in the traceability code. The traceability data should be continuously updated to record every turnover, so as to effectively prevent the occurrence of forged accounts.

Taking the chicken slaughtering segmentation as an example, the traceability code represents the complete life cycle information flow of a chicken. After slaughtering segmentation, the live chicken will be divided into chicken wings, chicken legs, chicken feet and other single products, which have their own single product code and unified batch code. When the information is linked, the time and space of the new data information must be verified, and the data can be linked only when the time and space of the previous flow 
information of the traceability code are consistent. Otherwise, the verification fails and the link is refused.

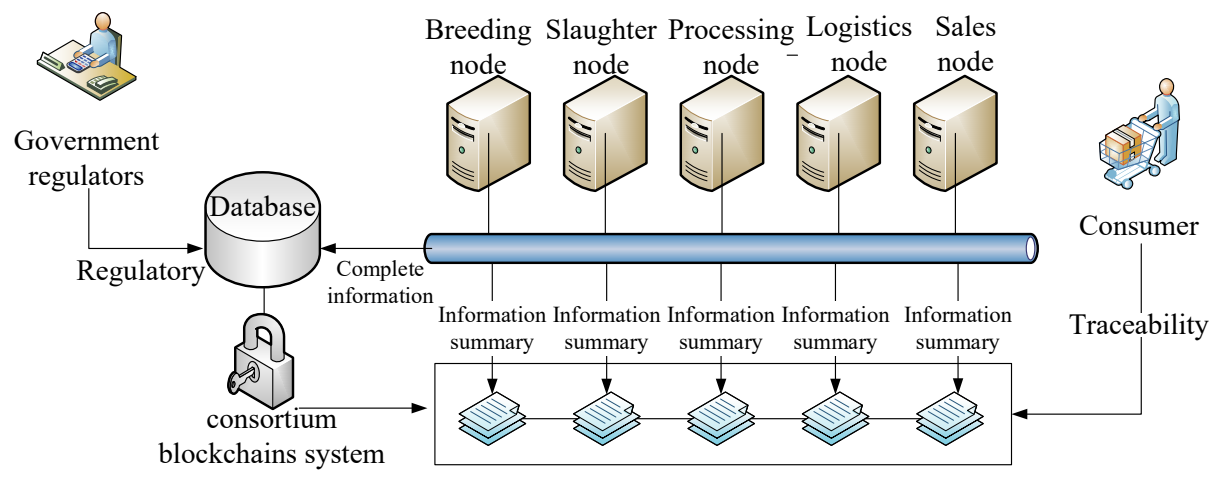

Fig. 2. Flow chart of chicken product traceability scheme.

\section{Case study}

\subsection{Status description}

Dezhou shaxiaoer Health Food Co., Ltd. is located in Yucheng high tech Development Zone, Dezhou, Shandong Province, which is founded in April 2004. It is a private enterprise with an area of more than $1.33 \mathrm{hm}^{2}$ and fixed assets of more than 10 million yuan. Its business scope covers the almost whole chicken product supply chain, including the screening and feeding of chicken breeds, the production and retails of grilled chicken. The company's leading products are aluminum foil bag vacuum grilled chicken, fresh grilled chicken, and chicken feet, chicken legs, chicken neck, chicken wings and other leisure food.

At present, the company has established a quality control system relying on the public service platform of food traceability in Shandong Province. However, due to the low degree of enterprise informatization, various processing ingredients and complex production process, the current quality control system only relies on the paper account of production and retails, which is difficult to form a perfect, efficient and safe traceability system.

\subsection{System design}

(1) Central management module: responsible for storing the data and information collected in each process of the supply chain, providing visual services for government regulatory departments, providing query functions for consumers.

(2) Breeding management module: responsible for collecting production data and uploading to the central management module. For their own breeding, breeding data can be collected by themselves. Upstream enterprises need to provide relevant supporting materials.

(3) Slaughtering management module: slaughtering is the most complex process in all process of the supply chain. Slaughtering enterprises need to complete chicken inspection and quarantine, segmentation and coding. 
(4) Processing management module: after slaughtering, processing enterprises need to complete the process of marinating or marinating chicken. At this time, the ingredients, accessories, packaging materials and other information need to be collected.

(5) Logistics management module: responsible for recording the moving track of products, which helps to understand where the products are going. logistics enterprises need to provide relevant certification materials.

(6) Retailing management module: retailing is the final part of the supply chain; products reach consumers through sales activities. Retails management module is responsible for recording the sales information of products, including retailer and distribution information.

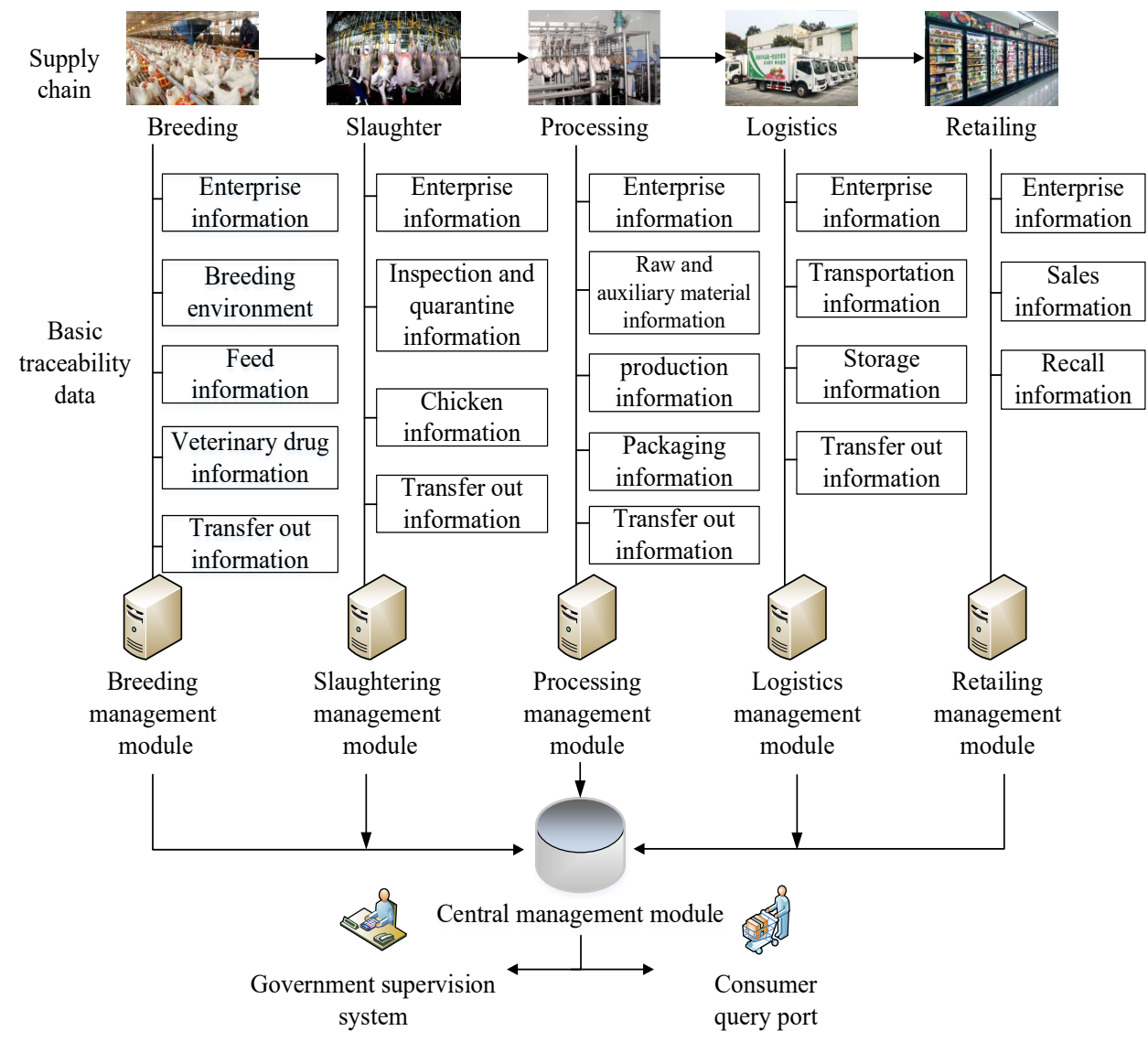

Fig. 5. Structure diagram of chicken product traceability system.

\section{Conclusion}

In this paper, HACCP is used to analyze and determine the key control points and traceability information in chicken supply chain, which solves the problem of chicken traceability at first. Then, because of the security and efficiency of the consortium blockchains, a chicken product traceability system based on the consortium blockchains is designed to realize the whole process tracking management of chicken and the reliable storage and sharing of trace data. 
This study is supported by National Key Technology R\&D Program of China (No.2016YFD0401205), Beijing Natural Science Foundation (No.4202014), Humanity and Social Science Youth Foundation of Ministry of Education of China (No.20YJCZH229), the R\&D Program of Beijing Municipal Education Commission (No.KM202010011011).

\section{References}

1. Li Huailin. General course of HACCP. Beijing: China Standards Press, 2002:67-111

2. Case application of blockchain technology in the field of traceability of agricultural products [n/OL]. Babbitt, [2020-01-03], http://www.btb8.com/blockchain/2001/84001.html.

3. Yang Jun. research on quality and safety management of chicken supply chain of SN Company [D]. Fujian Normal University, 2017

4. Zhou Shunji. Interpretation of Fujian local standard "technical specification for food quality and safety traceability code coding" [J]. Bar code and information system, 2019 (02): 25-27 